\title{
LETTERS
}

\section{Effect of steroid pulse therapy on mixed connective tissue disease with pulmonary arterial hypertension}

\author{
Y Kamata, H Nara, H Sato, J-I Masuyama, S Minota, T Yoshio
}

Ann Rheum Dis 2005;64:1236-1237. doi: 10.1136/ard.2004.029074

\begin{abstract}
A lthough the development of pulmonary arterial hypertension (PAH) in mixed connective tissue disease (MCTD) is now recognised as the most important life threatening factor, an effective treatment for PAH has not been established. The response to steroid treatment of PAH related to MCTD varies. Furthermore, Raynaud's phenomenon is the most common symptom of MCTD and one symptom of the 1996 revised criteria for MCTD in Japan. ${ }^{1}$ However, a reliable and consistently effective treatment for Raynaud's phenomenon in MCTD has not been established.

Sildenafil is reportedly effective for PAH and Raynaud's phenomenon in systemic sclerosis (SSc) and systemic lupus erythematosus (SLE). ${ }^{2-4}$ However, the effect of sildenafil on PAH and Raynaud's phenomenon in MCTD has not been reported.
\end{abstract}

\section{CASE REPORT}

We describe a case of PAH and Raynaud's phenomenon in a 39 year old female patient with MCTD, in which we evaluated the effects of steroids and sildenafil.

The patient had had dyspnoea on exertion and Raynaud's phenomenon since December 2002. Because of the worsening of dyspnoea on exertion, she was admitted to our hospital in November 2003. She was diagnosed as having MCTD based on the 1996 revised criteria for MCTD in Japan. ${ }^{1}$ Her symptoms and exercise capacity as defined by the New York Heart Association (NYHA) was functional class III. An echocardiogram showed right atrial and ventricular dilatation and the estimated pulmonary artery systolic pressure was $53.6 \mathrm{~mm} \mathrm{Hg}$ (resulting from tricuspid regurgitation identified on Doppler ultrasonography). Pulmonary function tests showed a diffusing capacity to alveolar volume ratio (TLCO/VA) of $78.0 \%$. She was diagnosed with PAH from these findings.

Methylprednisone pulse therapy ( $1 \mathrm{~g} /$ day for 3 consecutive days) followed by prednisone (50 mg/day) was started. She underwent right heart catheterisation before and 4 weeks after the start of steroid treatment. Mean pulmonary artery pressure declined from $39 \mathrm{~mm} \mathrm{Hg}$ to $28 \mathrm{~mm} \mathrm{Hg}$. The 6 minute walking distance increased from $100 \mathrm{~m}$ to $410 \mathrm{~m}$ and NYHA functional class improved from III to I. Furthermore, TLCO/VA increased from $78.0 \%$ to $87.9 \%$. Serum IgG antiendothelial cell antibody (AECA) titres measured as described before ${ }^{5}$ decreased from $45.0 \mathrm{U} / \mathrm{ml}$ to 6.0 U/ml (normal upper limit 7.14 U/ml).

Before the start of steroid treatment, the mean pulmonary artery pressure and pulmonary vascular resistance (PVR) measured by right heart catheterisation before and $40 \mathrm{~min}$ utes after the oral administration of sildenafil $(50 \mathrm{mg}$ ) were reduced by $10.3 \%$ and $28.9 \%$, respectively. Four weeks after the start of steroid treatment, the mean finger skin surface temperature of both hands by thermography before and 60 minutes after the oral administration of sildenafil $(50 \mathrm{mg}$ ) showed an increase of $6.4^{\circ} \mathrm{C}$ (fig 1 ).

\section{DISCUSSION}

Serum IgG AECA in this patient showed a high titre before the start of steroid treatment. Serum IgG AECA may reportedly be related to the appearance, development, and activity of PAH in $\mathrm{SLE}^{5}$ and MCTD. ${ }^{6}$ General case reports of the improvement of $\mathrm{PAH}$ during steroid or immunosuppressive treatment have been published. ${ }^{78}$ Based on these observations, PAH in this patient might be still in the early and active stage, which responded to steroid treatment. Early detection of PAH should allow an earlier and more aggressive therapeutic approach such as steroid pulse therapy in these patients, before irreversible vascular lesions occur.

Sildenafil increases intracellular cyclic guanosine monophosphate levels in vascular smooth muscle cells, thereby
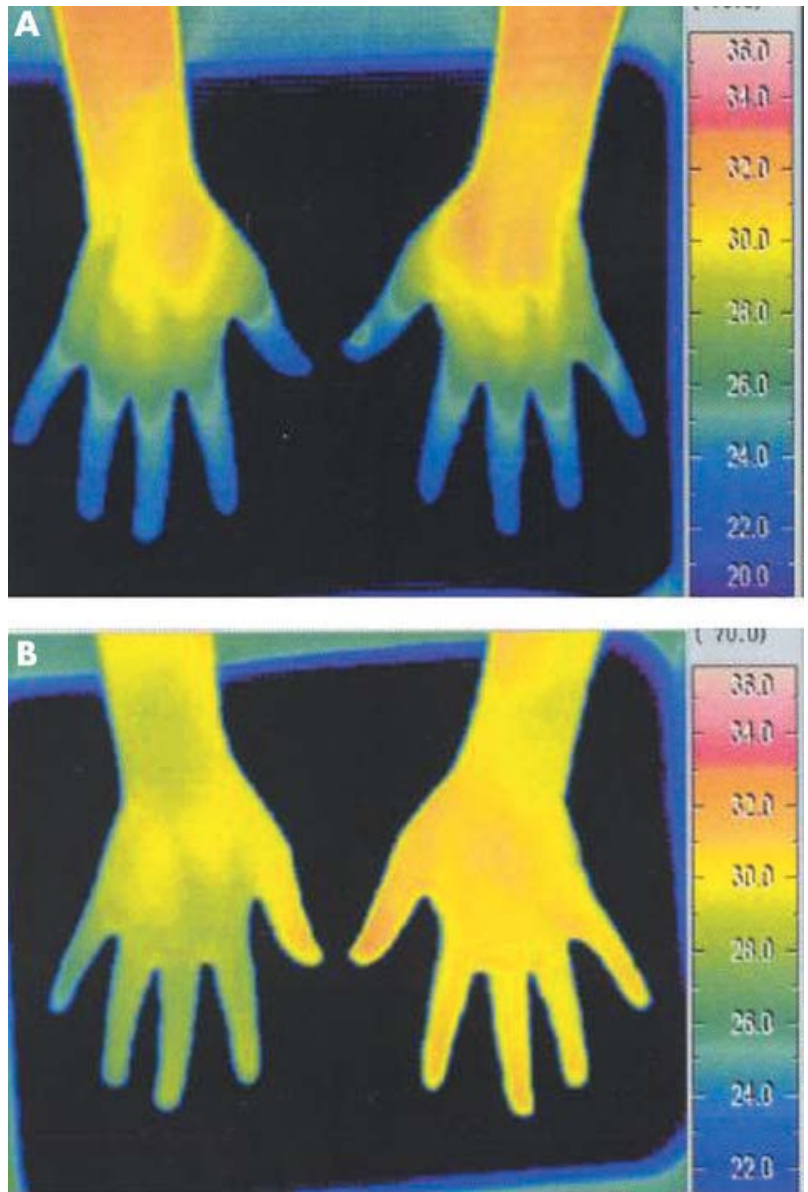

Figure 1 The finger skin surface temperature of both hands measured using an infrared thermal imaging camera, before (A) and 60 minutes after (B) the oral administration of sildenafil $(50 \mathrm{mg})$ in a temperature controlled room $\left(25 \pm 1^{\circ} \mathrm{C}\right)$, is shown by colour imaging. 
mediating vasorelaxation within 1 hour. In this patient a positive response-decrease of mean pulmonary artery pressure and PVR and increase of peripheral blood flowwas achieved by only a single oral administration of sildenafil. Sildenafil has been reported to be a selective pulmonary vasodilator ${ }^{9}$ but may also work as a vasodilator of peripheral arteries. These observations suggest that long term use of oral sildenafil may improve exercise tolerance and quality of life in MCTD patients with PAH and Raynaud's phenomenon.

\section{ACKNOWLEDGEMENTS}

This report was supported by a grant from the Ministry of Health, Labour, and Welfare of Japan.

\section{Authors' affiliations}

Y Kamata, H Nara, H Sato, J-I Masuyama, S Minota, T Yoshio, Division of Rheumatology and Clinical Immunology, Jichi Medical School, 3311 Yakushiii, Minamikawachi-machi, Tochigi-ken, 329-0498, Japan

Correspondence to: Dr T Yoshio, takuyosh@jichi.ac.jp

Accepted 2 January 2005

\section{REFERENCES}

1 Tojo T. The 1996 revised criteria for MCTD. Annual report of the research committee for mixed connective tissue disease of the Ministry of Health and Welfare of Japan 1996:3.

2 Rosenkranz S, Diet F, Karasch T, Weihranch J, Wassermann K, Erdmann E. Sildenafil improved pulmonary hypertension and peripheral blood flow in a patient with scleroderma-associated lung fibrosis and the Raynaud phenomenon. Ann Intern Med 2003;139:871-3.

3 Morina J, Lucero E, Luluaga S, Bellomio V, Spindler A, Berman A. Systemic lupus erythematosus-associated pulmonary hypertension: good outcome following sildenafil therapy. Lupus 2003;12:321-3.

4 Lichtenstein JR. Use of sildenafil citrate in Raynaud's phenomenon: comment on the article by Thompson et al. Arthritis Rheum 2003;48:282-3.

5 Yoshio T, Masuyama J-I, Sumiya M, Minota S, Kano K. Antiendothelial cell antibodies and their relation to pulmonary hypertension in systemic lupus erythematosus. J Rheumatol 1994;21:2058-63.

6 Nishimaki T, Aotsuka S, Kondo H, Yamamoto K, Takasaki Y, Sumiya M, et al. Immunological analysis of pulmonary hypertension in connective tissue diseases. J Rheumatol 1999:26:2357-62.

7 Mariette X, Brenot F, Brouet JC. Recovery from pulmonary hypertension with steroid therapy in a patient with Sjögren's syndrome and polymyositis. J Rheumatol 1994;21:772-3.

8 Sanchez O, Sitbon O, Garcia G, Jais X, Simonneau G, Humbert M. Pulmonary artery hypertension associated with connective tissue diseases. Presse Med 2003;32:789-99.

9 Ghofrani HA, Pepke-Zaba J, Barbera JA, Channick R, Keogh AM, Gomez-Sanchez MA, et al. Nitric oxide pathway and phosphodiesterase inhibitors in pulmonary arterial hypertension. J Am Coll Cardiol 2004;43(suppl S):68-72S.

\section{Anti-midbody antibodies as a possible predictive factor for a special limited or abortive form of systemic sclerosis?}

\section{A K Tausche, K Conrad, W Seidel, B Roch}

Ann Rheum Dis 2005;64:1237-1238. doi: 10.1136/ard.2004.034116

A utoantibodies $(\mathrm{AAb})$, typically detectable in sera of patients with systemic sclerosis (SSc), are more or less specific and directed against DNA topoisomerase I ( Scl70), centromeric (CENP-B) and nucleolar (fibrillarin, RNA polymerases, Th/To, $\mathrm{PM} / \mathrm{Scl}$ ) antigens and are found also in mixed connective tissue diseases or even before disease manifestation. ${ }^{12}$ In rare cases, AAb to cell cycle associated antigens of the centriole/centrosome, the nuclear mitotic apparatus, the stem body, the cleavage furrow, and the midbody region can be found..$^{3-5}$ In the mid-1980s two separate groups described anti-midbody antibodies (aMB) in five patients with SSc and in one patient with Raynaud's syndrome. ${ }^{45}$ The target antigen(s) of aMB are still unknown proteins of the cleavage furrow and the midbody region of dividing cells and are detected by indirect immunofluorescence on tumour cell monolayer (HEp-2).

\section{CASE REPORT}

A 61 year old woman first presented in 1999 with a history of more than 15 years' Raynaud's syndrome. A first examination showed skin sclerosis with periorally intensified radial skinfolding, reduced mouth opening with an extensive frenulum sclerosis (figs $1 \mathrm{~A}$ and $\mathrm{B}$ ), xerostomia, and classic cutaneous sclerosis with diminished skin foldability over all fingers. There were no scarred healed finger pad ulcerations, calcinosis, or telangiectasias and only discrete changes of the nail fold. Clinical examination and laboratory tests showed normal results. Indirect immunofluorescence showed aMB at high titres of $1 / 2560$, but no other AAb, were detectable (fig 2). Further examinations (radiographs, high resolution computed tomography, thorax, capillary microscopy, oesophagoscintigraphy, gastroscopy, pulmonary function tests, echocardiography, abdominal sonography) did not show pathological findings.

An updated organ staging was performed in May 2004. No internal organ manifestation of SSc or a malignant disease could be found.

\section{DISCUSSION}

For the classification of definite SSc, American College of Rheumatology criteria are used. ${ }^{7}$ However, these criteria are very often too insensitive for early SSc and cannot be used for variants of SSc such as "sclerosis sine scleroderma". Also, according to the LeRoy criteria- a scleroderma classification that depends on the extent of skin involvement-our patient does not fulfil the demanded criteria. ${ }^{9}$ All findings merged, there is no further evidence of an internal organ involvement encompassed by SSc apart from the mucocutaneous signs.

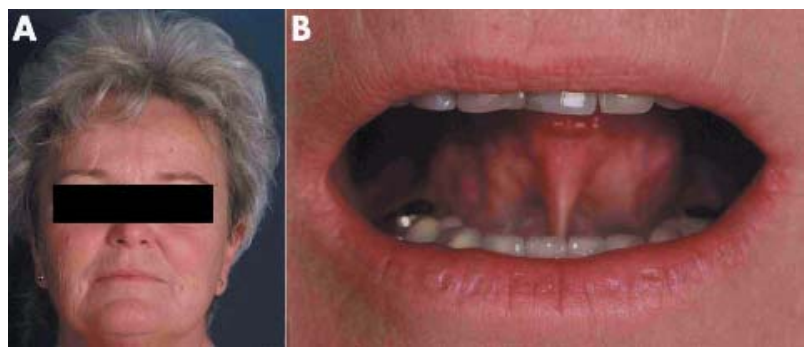

Figure 1 Periorally intensified radial skinfolding. (A) Extensive frenulum sclerosis; (B) reduced maximal mouth opening. Reproduced with permission of the patient. 


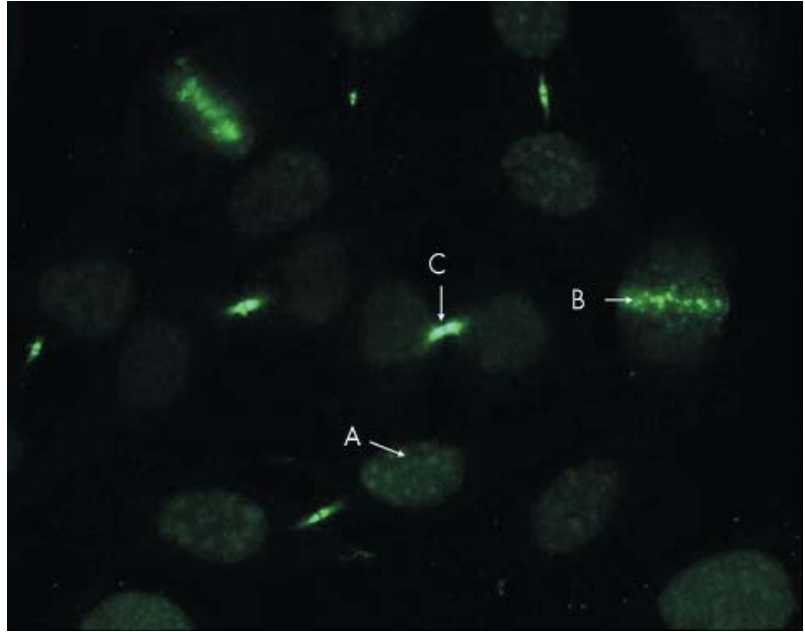

Figure 2 Serum samples sequentially taken from the described patient between March 1999 and May 2004 showed a cell cycle associated immunofluorescence pattern by indirect immunofluorescence on HEp-2 cells typical for $a \mathrm{MB}^{6}$ : no, weak or stronger granular staining of interphase nuclei (A), strong staining of prometaphase and metaphase chromatin, of the cleavage furrow (B) of anaphase and the midbody region $(C)$ of telophase cells.

$\mathrm{AAb}$ against antigen(s) of the midbody region are rarely described. They seem to be associated with SSc and Raynaud's syndrome and were found in one patient with primary hepatocellular carcinoma. ${ }^{4-6}$ The data published in the mid-1980s give no information about the duration of the Raynaud's syndrome. Also in the case of idiopathic Raynaud's syndrome the patient was not followed up for a longer period to exclude a later manifestation of SSc. Many relevant questions-for example, the prevalence of aMB in a normal population, their association with other diseases, and the antigens targeted, have not been answered up to now. As we do not routinely examine for aMB, it can be assumed that patients with aMB may very often remain unrecognised. The results of Fritzler et al, as well as our own examinations on more than 1000 blood donors (unpublished results), demonstrate that $\mathrm{aMB}$ are not detectable in people without disease and therefore seem to be disease associated. ${ }^{10}$

Because of the typical skin changes in our patient who had 15 years of Raynaud's syndrome in combination with a special autoantibody response, a special limited or incomplete, benign variant of SSc, is suggested.

The role of aMB as a predictive factor of such a minimal variant of SSc remains unclear. Only an evaluation of these antibodies in combination with a follow up of as many patients as possible could provide further answers to these questions.

\section{Authors' affiliations}

A K Tausche, B Roch, Section for Internal Medicine, Department of Rheumatology, University Clinic Carl Gustav Carus, Dresden University of Technology, Fetscherstrasse 74, D-01307 Dresden, Germany

K Conrad, Institute for Immunology, University Clinic Carl Gustav Carus, Dresden University of Technology, Fetscherstrasse 74, D-01307 Dresden, Germany

W Seidel, Medical Clinic IV, Department of Rheumatology, University Clinic Leipzig, Liebigstrasse 22, D-04103 Leipzig, Germany

Correspondence to: Dr A-K Tausche, anne-kathrin.tausche@ mailbox.tu-dresden.de

Accepted 7 February 2005

\section{REFERENCES}

1 Ho KT, Reveille JD. The clinical relevance of autoantibodies in scleroderma. Arthritis Res Ther 2003;5:80-93.

2 Weiner ES, Hildebrandt S, Senécal JL, Daniels L, Noell S, Joyal F, et al. Prognostic significance of anticentromere antibodies and anti-topoisomerase I antibodies in Raynaud's disease. Arthritis Rheum 1991;34:68-77.

3 Kingwell B, Fritzler MJ, Decoteau J, Rattner JB. Identification and characterization of a protein associated with the stembody using autoimmune sera from patients with systemic sclerosis. Cell Motil Cytoskeleton 1987;8:360-7.

4 Senecal JL, Oliver JM, Rothfield N. Anticytoskeletal autoantibodies in the connective tissue diseases. Arthritis Rheum 1985;28:889-98.

5 Fritzler MJ, Ayer LM, Gohill J, O'Connor C, Laxer RM, Humbel RL. An antigen in metaphase chromatin and the midbody of mammalian cells binds to scleroderma sera. J Rheumatol 1986;14:291-4.

6 Fang F, Wang HL, Ye P, Deng HL, Dong GL, Ma LL, et al. Detection of autoantibodies in the serum of primary hepatocarcinoma patients. Hepatobiliary Pancreat Dis Int 2002;1:94-5.

7 ARA. Subcommittee for Scleroderma Criteria of the American Rheumatism Association Diagnostic and Therapeutic Criteria Committee. Preliminary criteria for the classification of systemic sclerosis (scleroderma). Arthritis Rheum 1980;23:581-90.

8 Poormoghim H, Lucas M, Fertig N, Medsger TA. Systemic sclerosis sine scleroderma. Demographic, clinical, and serologic features and survival in forty-eight patients. Arthritis Rheum 2000;43:444-51

9 LeRoy EC, Black C, Fleischmajer R, Jablonska S, Krieg T, Medsger TA, et al Scleroderma (systemic sclerosis): classification, subsets and pathogenesis. J Rheumatol 1988;15:202-5.

10 Fritzler MJ, Pauls JD, Kinsella D, Bowen T. Antinuclear, anticytoplasmic, and anti-Sjögren's syndrome antigen A (SS-A/Ro) antibodies in female blood donors. Clin Immunol Immunopathol 1985;36:120-8.

\section{An unusual presentation of Wegener's granulomatosis mimicking thymoma}

\section{C-R Wang, J-M Chang, W-L Shen, W-J Lin, J Y-Y Lee, M-F Liu}

Ann Rheum Dis 2005;64:1238-1240. doi: 10.1136/ard.2004.031617

$\mathrm{P}$ ulmonary manifestations of Wegener's granulomatosis (WG) range from asymptomatic nodules, fleeting infiltrates to alveolar haemorrhage. ${ }^{1}$ A mediastinal mass was considered an unlikely feature of WG and its presence was regarded as an alternative diagnosis. ${ }^{2}$ We report on a patient with WG who presented with a mediastinal mass and an elevation of the left hemidiaphragm, initially thought to be thymoma. Thymectomy disclosed extensive inflammation composed of necrotising vasculitis and extravascular

granuloma. To our knowledge, this unusual presentation of WG mimicking thymoma has not been reported previously.

\section{CASE REPORT}

A 34 year old man was referred to our hospital with a thymic tumour. The patient had had vague chest pain for 1 year and, 3 weeks before admission, the pain became aggravated. There was no past history of allergic diseases such as bronchial asthma. At hospital chest radiography showed a 

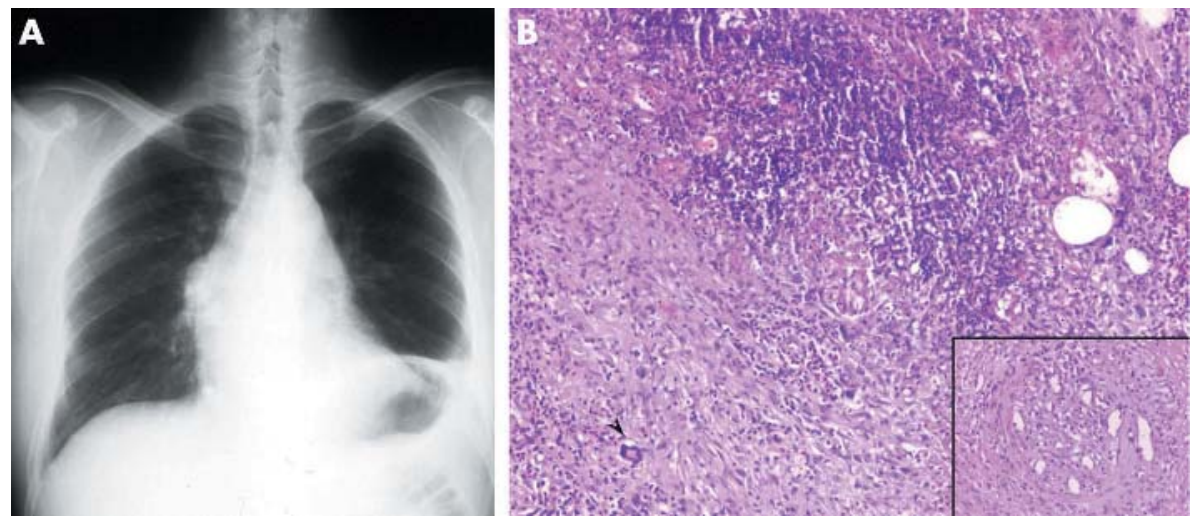

Figure 1 (A) A chest $x$ ray examination showed a wide mediastinum with an elevation of the left hemidiaphragm. (B) Pathological examination showed extensive acute inflammation composed of necrotising vasculitis affecting small sized vessels (inset, original magnification $\times 200$ ), extravascular granulomas with multinucleated giant cell formation (arrowhead), and prominent inflammatory infiltration (haematoxylin and eosin, original magnification $\times 100$ ).

wide mediastinum with an elevation of the left diaphragm (fig lA), and chest computed tomography (CT) disclosed a lobulated tumour in the anterior mediastinum with an ill defined margin extending from the aortic arch to the precordial region, and subcarinal lymphadenopathy.

On examination, vital signs were stable and others were unremarkable. Laboratory tests showed leucocytes $13.8 \times 10^{9} / 1$ with $10.7 \%$ eosinophils, platelets $505 \times 10^{9} /$, and erythrocyte sedimentation rate $50 \mathrm{~mm} / \mathrm{lst} \mathrm{h}$. The patient received thymectomy, and pathological examination showed extensive inflammation composed of necrotising vasculitis affecting small to medium sized vessels, and extravascular granuloma with multinucleated giant cell formation (fig 1B). The antineutrophil cytoplasmic antibody was positive ( $\times 160$ cytoplasmic type) and other autoantibody tests were negative.

Sudden onset of dyspnoea with haemoptysis occurred and CT disclosed bilateral diffuse consolidation compatible with alveolar haemorrhage. Methylprednisolone pulse therapy $1 \mathrm{~g}$ for 3 days was prescribed and followed by daily prednisolone $1 \mathrm{mg} / \mathrm{kg}$. Nasal mucosa ulcerations and palpable purpura were noted. A skin biopsy showed leucocytoclastic vasculitis.

After taking account of the clinical manifestations, pathological findings, and serological tests, the diagnosis of WG was concluded. Cyclophosphamide treatment was started with daily Endoxan $2 \mathrm{mg} / \mathrm{kg}$. However, proptosis of the eyes and bilateral hand ischaemic changes appeared. Renal function deteriorated, with microscopic haematuria (70-80 red blood cells/high power field, proteinuria ( $1.2 \mathrm{~g} /$ $24 \mathrm{~h})$, and raised blood creatinine levels $(210 \mu \mathrm{mol} / \mathrm{l})$. An etanercept injection $25 \mathrm{mg}$ twice a week was added. Disease activity subsided gradually and the elevation of the hemidiaphragm was reversed. Daily prednisolone and Endoxan doses were tapered to $0.5 \mathrm{mg} / \mathrm{kg}$ and $1 \mathrm{mg} / \mathrm{kg}$, respectively and etanercept was discontinued after 2 months.

Neutropenia was noted and Endoxan was withheld. Swallowing difficulty with pain developed. Endoscopy showed oesophagitis with ulcerations, and an oesophagogram showed a narrow lumen with poor motility. Respiratory failure was noted and the patient received bronchoscopy and a CT examination, which disclosed lower tracheal and endobronchial stenosis with diffuse wall thickening and lumen narrowing. His disease was complicated with several episodes of infection, including pneumonia, cellulitis, and urinary tract infection. High dose steroid treatment (prednisolone $1 \mathrm{mg} / \mathrm{kg} /$ day) was continued, but Endoxan was not prescribed. He died from sepsis 7 months later after admission to hospital.

\section{DISCUSSION}

A fulminant disease with a full pattern of organ involvement was found in our patient. Churg-Strauss syndrome does not produce destructive airway disease such as endobronchial stenosis or alveolar haemorrhage, and occurs exclusively in patients with asthma. ${ }^{3}$ Blood and tissue eosinophils have been found in WG. ${ }^{4}$

Respiratory involvement is a common manifestation of WG; however, mediastinal manifestations, both as presenting events or during the course of disease, are rare. ${ }^{1}$ In a comprehensive review of 302 patients with WG, only three cases had mediastinal masses. ${ }^{2}$ Unilateral phrenic nerve paralysis with hemidiaphragmatic elevation was recognised in only one patient with WG without any mediastinal mass. ${ }^{5}$ The hemidiaphragmatic elevation in that case occurred at the late stage independently of disease flare.

Our patient received conventional treatment and etanercept treatment. Tumour necrosis factor $\alpha$ has a central role in inflammation and granuloma formation, and current experimental approaches to the treatment of WG include strategies designed to disrupt tumour necrosis factor $\alpha .{ }^{6}$ A preliminary study of etanercept treatment showed an encouraging effect in WG and randomised trials were under way. ${ }^{7}$

A mediastinal mass with left hemidiaphragmatic elevation mimicking thymoma has not been reported previously in patients with WG. It is important to recognise the presenting features of WG, because early treatment is essential for a favourable outcome.

\section{Authors' affiliations \\ C-R Wang, M-F Liu, Section of Rheumatology, Department of Internal Medicine, College of Medicine, National Cheng Kung University, Tainan, Taiwan \\ J-M Chang, Section of Thoracic Surgery, Department of Surgery, College of Medicine, National Cheng Kung University, Tainan, Taiwan W-L Shen, Department of Pathology, College of Medicine, National Cheng Kung University, Tainan, Taiwan \\ W-J Lin, Section of Pulmonary Medicine, Department of Internal Medicine, College of Medicine, National Cheng Kung University, Tainan, Taiwan \\ J Y-Y Lee, Department of Dermatology, College of Medicine, National Cheng Kung University, Tainan, Taiwan}

Correspondence to: Dr C-R Wang, wangcr@mail.ncku.edu.tw

Accepted 28 December 2004 


\section{REFERENCES}

1 Fauci AS, Haynes BF, Katz P, Wolff SM. Wegener's granulomatosis: prospective clinical and therapeutic experience with 85 patients for 21 years. Ann Intern Med 1983;98:76-85

2 George TM, Cash JM, Farver C, Sneller M, van Dyke CW, Derus CL, et al. Mediastinal mass and hilar adenopathy. Arthritis Rheum 1997;40:1992-7.

3 Katzenstein A-L A. Diagnostic features and differential diagnosis of ChurgStrauss syndrome in the lung. Am J Clin Pathol 2000;1 14:767-72.

4 Yousem SA, Lombard CM. Eosinoplilia variant of Wegener's granulomatosis. Hum Pathol 1988; 19:682-8.
5 Pamuk ON, Dogutan H, Pamuk GE, Cakir N. Unilateral phrenic nerve paralysis in a patient with Wegener's granulomatosis. Rheumatol Int 2003;23:201-3.

6 Ludviksson BR, Sneller MC, Chua KS, Talar-Williams C, Langford CA Ehrhardt RO, et al. Active Wegener's granulomatosis is associated with HLADR+ CD4+ T cells exhibiting an unbalanced Th1-type T cell cytokine pattern: reversal with IL-10. J Immunol 1998;160:3602-9.

7 Stone JH, Uhlfelder ML, Hellmann DB, Crook S, Bedocs NM, Hoffman GS. Etanercept combined with conventional treatment in Wegener's granulomatosis: a six-month open-label trial to evaluate safety. Arthritis Rheum 2001;44:1149-54.

\section{Siögren's syndrome: a population based study of prevalence in Greece. The ESORDIG study}

\section{P I Trontzas, A A Andrianakos}

$\mathrm{P}$ rimary Sjögren's syndrome (pSS) is a chronic autoimmune disease characterised by lymphocytic infiltration of the exocrine glands, presenting chiefly with keratoconjunctivitis sicca and xerostomia. Estimates of the prevalence of pSS have varied widely among population based surveys, partly because of the different classification criteria used and partly because of methodological differences. We previously reported the prevalence of pSS as $0.15 \%$, in the ESORDIG study, ${ }^{1}$ and we now report more detailed information about these patients and compare our findings with those from other studies.

The ESORDIG study was a cross sectional epidemiological study of the rheumatic diseases in Greece (target the adult white population: 10647 residents; fig 1). The preliminary European (EU) criteria for the classification of pSS were used. ${ }^{2}$ Subjects who responded positively during the interview to one or more of the three specific questions related to oral symptoms and/or to one or more of the three specific questions related to ocular symptoms were subsequently evaluated by the investigators (medical history, clinical examination, consideration of available laboratory findings). When necessary, procedures for the four objective EU criteria items were carried out until pSS was diagnosed or until three out of the six criteria items were negative. Because the EUUSA consensus group has recently published a revised version of the above criteria, we present our data in accordance with these revised criteria. ${ }^{3}$

We found 13 patients with pSS (1 man, 12 women, mean (SD) age 55 (16); table 1). Possible cases were not included in our calculations. Thus, the estimate of the age and sex adjusted point prevalence of pSS in both sexes was $0.15 \%$, (95\% confidence interval (CI) 0.09 to 0.21 ) and in the female population $0.29 \%$ (95\% CI 0.16 to 0.42 ). The prevalence was higher in the elderly and among residents of urban areas (table 1).

Our estimate is lower than that of studies in Manchester $(3.3 \%)^{4}$ and in Slovenia $(0.60 \%)^{5}$ (both of which used the preliminary EU criteria), and also lower than that of a study in China $(0.33 \%$ and $0.77 \%$, according to modified San Diego

\section{Target adult population ( $\geq 19$ years) ( $n=10647)$}

Figure 1 Flow chart of the ESORDIG study design. 
Table 1 Primary Siögren's syndrome cases of the ESORDIG study: patients' characteristics

\begin{tabular}{|c|c|c|c|c|c|c|c|c|c|}
\hline Patient No & o Sex & Age $^{*}$ & Residence† & $\begin{array}{l}\text { Ocular } \\
\text { symptoms }\end{array}$ & Oral symptoms $\ddagger$ & Ocular signsł & $\begin{array}{l}\text { Histo- } \\
\text { pathologył }\end{array}$ & $\begin{array}{l}\text { Salivary gland } \\
\text { involvementł }\end{array}$ & $\begin{array}{l}\text { Autoantibodies } \neq \\
\text { (SSA/SSB) }\end{array}$ \\
\hline 1 & $\mathrm{~F}$ & 52 & u & & + & & + & + & + \\
\hline 2 & $\mathrm{~F}$ & 48 & U & + & + & + & + & & \\
\hline 3 & $\mathrm{~F}$ & 36 & u & + & + & & + & + & \\
\hline 4 & $\mathrm{~F}$ & 69 & U & + & + & + & + & & \\
\hline 5 & $\mathrm{~F}$ & 42 & U & + & + & + & + & & \\
\hline 6 & $\mathrm{~F}$ & 67 & U & + & + & + & + & & \\
\hline 7 & $\mathrm{~F}$ & 46 & U & + & + & + & + & & \\
\hline 8 & M & 75 & $\mathrm{~s}$ & + & + & + & & & + \\
\hline 9 & $\mathrm{~F}$ & 48 & $\mathrm{~s}$ & + & + & + & & & + \\
\hline 10 & $\mathrm{~F}$ & 78 & $\mathrm{~s}$ & + & + & + & + & & \\
\hline 11 & $\mathrm{~F}$ & 42 & $\mathrm{~s}$ & + & + & + & & & + \\
\hline 12 & $\mathrm{~F}$ & 33 & $\mathrm{R}$ & + & & + & + & & + \\
\hline 13 & $\mathrm{~F}$ & 80 & $\mathrm{R}$ & + & + & + & + & + & \\
\hline
\end{tabular}

*A significantly higher prevalence of pSS was noted in the $\geqslant 65$ year age group $(0.40 \%)$ than in the $19-44(0.11 \%)$ and the $45-64(0.08 \%)$ year age groups, $(p<0.02)$; thigher prevalence of $\mathrm{pSS}$ (but not significant) was noted among urban $(0.26 \%)$ than suburban $(0.15 \%)$ and rural areas $(0.07 \%)$; ¥according to the EUUSA revised classification criteria for primary Siögren's syndrome. ${ }^{3}$

$F$, female; $M$, male; $U$, urban; $S$, suburban; $R$, rural.

and Copenhagen criteria, respectively). ${ }^{6}$ Apart from the different sets of criteria used, other methodological differences may be the reason for these discrepancies. The initial phase involving a questionnaire sent by post in some surveys results in a low response rate $(37.3-61.6 \%),{ }^{45}$ and this is one of the most likely causes of bias. In addition, the population in some of the studies was non-white ${ }^{6}$ or not exclusively white, ${ }^{4}$ and genetic differences may influence the results.

We found almost half the prevalence in the female population of that reported in a previous study in a Greek village $(0.60 \%) .^{7}$ There is no apparent explanation for this discrepancy, although it should be noted that there was an overlapping of the $95 \%$ CI between the two studies. The ESORDIG study involved a large sample size, conducted in many dispersed areas around Greece, and the study population was representative of the general adult population of the country. ${ }^{1}$ There may have been a very slight underestimate in our data, because in a community study it is impossible to determine the, perhaps only few, patients with pSS who fulfilled three of the four objective criteria but who were without oral or ocular symptoms. Nevertheless, our results were close to those in recent reports from Birmingham, UK $0.14 \%$ up to $0.40 \%$ in the female population $)^{8}$ and from Izmir, Turkey $(0.21 \%$ in both sexes $),{ }^{9}$ both of which used EU-USA criteria. The above may be evidence that the prevalence of pSS in the general white population is lower than previously thought.

\section{Authors' affiliations}

P I Trontzas, Rheumatology Department, 3rd IKA Hospital, Athens, Greece
A A Andrianakos, Rheumatic Disease Epidemiology Section, Hellenic Foundation for Rheumatological Research, Athens, Greece

Correspondence to: Dr P I Trontzas, Plastira 72, Nea Smirni, 17121 Athens, Greece; pantron@otenet.gr

Accepted 28 December 2004

\section{REFERENCES}

1 Andrianakos A, Trontzas P, Christoyiannis F, Dantis P, Voudouris C, Georgountzos A, et al. Prevalence of rheumatic diseases in Greece: a crosssectional population-based epidemiological study. The ESORDIG study. J Rheumatol 2003;30:1589-601.

2 Vitaly C, Bombardieri S, Moutsopoulos HM, Balestrieri G, Bencivelli W, Bernstein R, et al. Preliminary criteria for the classification of Sjögren's syndrome: results of a prospective concerted action supported by the European Community. Arthritis Rheum 1993;36:340-7.

3 Vitaly C, Bombardieri S, Jonsson R, Moutsopoulos HM, Alexander EL, Carsons SE, et al. Classification criteria for Siögren's syndrome: a revised version of the European criteria proposed by the American-European Consensus Group. Ann Rheum Dis 2002;61:554-8.

4 Thomas E, Hay EM, Hajeer A, Silman AJ. Sjögren's syndrome: a communitybased study of prevalence and impact. Br J Rheumatol 1998;37:1069-76.

5 Tomšič M, Logar D, Grmek M, Perkovič T, Kveder T. Prevalence of Siögren's syndrome in Slovenia. Rheumatology (Oxford) 1999;38:164-70.

6 Zhang NZ, Shi CS, Yao QP, Pan GX, Wang LL, Wen ZX, et al. Prevalence of primary Siögren's syndrome in China. J Rheumatol 1995;22:659-61.

7 Dafni U, Tzioufas A, Staikos P, Skopouli F, Moutsopoulos H. Prevalence of Sjögren's syndrome in a closed rural community. Ann Rheum Dis 1997;56:521-5.

8 Bowman SJ, Ibrahim GH, Holmes G, Hamburger J, Ainsworth JR. Estimating the prevalence among Caucasian women of primary Siögren's syndrome in two general practices in Birmingham, UK. Scand J Rheumatol 2004;33:39-43.

9 Birlik M, Akar S, Gurler O, Sari I, Sarioglu S, Birlik B, et al. Prevalence of primary Siögren's syndrome in an urban population of Izmir, Turkey [abstract]. Ann Rheum Dis 2004;63(suppl I):502.

\section{Methotrexate effect on anti-cyclic citrullinated peptide antibody levels in rheumatoid arthritis}

\section{A Spadaro, V Riccieri}

Ann Rheum Dis 2005;64:1241-1242. doi: 10.1136/ard.2004.032136

W read with interest the recent reports ${ }^{1-3}$ focusing on the changes of rheumatoid factor and anti-citrullinated peptide antibodies (anti-CCP) during infliximab treatment in refractory rheumatoid arthritis (RA), unresponsive to conventional disease modifying antirheumatic drugs.

Alessandri et $a l^{3}$ reported that 24 weeks' infliximab treatment reduced anti-CCP levels according to the study of 
Table 1 Clinical and laboratory changes from baseline in patients with or without anti-CCP antibodies after 6 months' MTX treatment

\begin{tabular}{lll}
\hline $\begin{array}{l}\text { Change from } \\
\text { baseline }\end{array}$ & $\begin{array}{l}\text { Anti-CCP positive } \\
(\mathbf{n}=14)\end{array}$ & $\begin{array}{l}\text { Anti-CCP negative } \\
(\mathbf{n}=6)\end{array}$ \\
\hline ACR $<20 \%$, No $(\%)$ & $3(21)$ & $1(17)$ \\
ACR 20\%, No (\%) & $9(64)$ & $2(33)$ \\
ACR 50\%, No (\%) & $1(7)$ & $1(17)$ \\
ACR 70\%, No (\%) & $1(7)$ & $2(33)$ \\
CRP (mg/l) & $0(0-6)$ & $15(0-24)$ \\
ESR (mm/1st h) & $16(7-30)$ & $23(4-25)$ \\
IgM RF (BI) & $0.7(0.4-1.7)$ & $0.3(0-1.8)$ \\
\hline
\end{tabular}

None of the differences were significant

Bobbio-Pallavicini et al. ${ }^{2}$ These results are in contrast with the findings of De Rycke et al, which showed no change of this autoantibody serum level after 30 weeks' infliximab treatment. ${ }^{1}$ However, the levels of anti-CCP returned to baseline values after a long term observation ( 78 weeks). ${ }^{2}$ In these studies infliximab was frequently associated with methotrexate (MTX), and selection criteria included patients previously treated with MTX. The sole MTX effect on antiCCP levels cannot be assessed from these reports. For this reason we studied MTX effect on anti-CCP in patients with RA not previously treated with this drug. We determined anti-CCP antibodies (Axis Shields, Dundee, UK) and IgM rheumatoid factor $(\mathrm{RF})^{4}$ by enzyme linked immunosorbent assay (ELISA) at baseline and after 6 months of MTX treatment (dose range 7.5-15 mg/weekly) in 20 patients with RA (mean age 56.6 years (range 39-68); mean disease duration 7.6 years (range 1-21)). Anti-CCP and RF positive samples were respectively defined as $\geqslant 20$ units and as binding index (BI) $>1$. A comparison of these autoantibody levels (median (25th-75th centile)) at baseline and after 6 months of MTX treatment showed that anti-CCP antibody levels were not modified (49.5 (15-77) v 59.5 (5-74) U; NS), whereas IgM RF levels were significantly reduced (4.1 (1.45.9) v $2.4(0.4-4.1) \mathrm{BI} ; \mathrm{p}<0.0001)$.
At baseline, the presence of anti-CCP antibodies does not seem to be a predictive factor of clinical and laboratory response, evaluated by American College of Rheumatology (ACR) response rate, erythrocyte sedimentation rate, $\mathrm{C}$ reactive protein, and IgM RF reduction after 6 months' MTX treatment (table 1 ). We observed that only $\mathrm{C}$ reactive protein reduction seemed to be more evident, although not significant, in patients without anti-CCP antibodies at baseline.

Our observations showed the lack of MTX effect on antiCCP production, suggesting that the discrepant results on restricted subsets of patients with RA treated with a tumour necrosis factor blocking agent ${ }^{1-3}$ could not be due to previous or concomitant treatment with MTX. Additionally, our results confirm that anti-CCP antibodies and RF are two independent autoantibody systems.

\section{Authors' affiliations}

A Spadaro, V Riccieri, Dip. Clinica e Terapia Medica Applicata-Div, Reumatologia-Università "La Sapienza" Rome, Italy

Correspondence to: Professor A Spadaro, a.spadaro.reuma@virgilio.it

Accepted 16 December 2004

\section{REFERENCES}

1 De Rycke L, Verhelst X, Kruithof E, Van den Bosch F, Hoffmann IEA, Veys EM, et al. Rheumatoid factor, but not anti-citrullinated protein antibodies, is modulated by infliximab treatment in rheumatoid arthritis. Ann Rheum Dis. 2005;64: 299-302 doi, 10.1136/ard.2004.023523 [published Online First:27 May 2004].

2 Bobbio-Pallavicini F, Alpini C, Caporali R, Avalle S, Bugatti S Montecucco M. Autoantibody profile in rheumatoid arthritis during long-term infliximab treatment. Arthritis Res Ther. 2004;6: R264-72, Epub 26 April, 2004.

3 Alessandri C, Bombardieri M, Papa N, Cinquini M, Magrini L, Tincani A, et al. Decrease of anti-cyclic citrullinated peptide antibodies and rheumatoid factor following anti-TNF $\alpha$ therapy (infliximab) in rheumatoid arthritis is associated with clinical improvement. Ann Rheum Dis 2004;63:1218-21.

4 Spadaro A, Riccieri V, Sili Scavalli A, Taccari E, Zoppini A. One year treatment with low dose methotrexate in rheumatoid arthritis: effect on class specific rheumatoid factors. Clin Rheumatol 1993;12:357-60.

\section{Leucoencephalopathy after treatment of Churg-Strauss syndrome with interferon $\alpha$}

\section{Metzler, P Lamprecht, B Hellmich, M Reuter, A-C Arlt, W L Gross}

W e have reported the successful induction of remission with interferon $\alpha$ (IFN $\alpha)$ in severe ChurgStrauss syndrome (CSS) refractory to treatment with corticosteroid and cyclophosphamide. ${ }^{1}$ The effectiveness and safety of short term administration of IFN $\alpha$ was confirmed by a subsequent case series. ${ }^{2}$ Now, we report a potentially hazardous adverse event seen in two of 12 patients with CSS during long term IFN $\alpha$ treatment.

\section{CASE REPORTS}

The first patient was a 48 year old woman with biopsy proven CSS, fulfilling the American College of Rheumatology criteria and Chapel Hill Consensus Conference definition, with blood eosinophilia, involvement of the respiratory tract, skin, peripheral nervous system, musculoskeletal system, and heart. Remission was induced with cyclophosphamide and corticosteroid for 10 months and maintained with methotrexate for 12 months, but she then relapsed with eosinophilic pleural effusion and pulmonary infiltrates. To avoid prolonged administration of cytotoxic drugs she received $3 \times 3-3 \times 7.5$ million units IFN $\alpha /$ week subcutaneously. Remission with IFN $\alpha$ lasted for 61 months when a pulmonary relapse occurred. Surprisingly, magnetic resonance imaging (MRI) of the head, performed for staging of ear, nose, and throat activity, disclosed multifocal leucoencephalopathy (fig 1) in the absence of neurological signs and in contrast with previous images obtained 74 and 47 months previously. The cerebrospinal fluid (CSF) was normal. Infectious and other causes were excluded. Treatment was switched to methotrexate. During 24 months of follow up she 


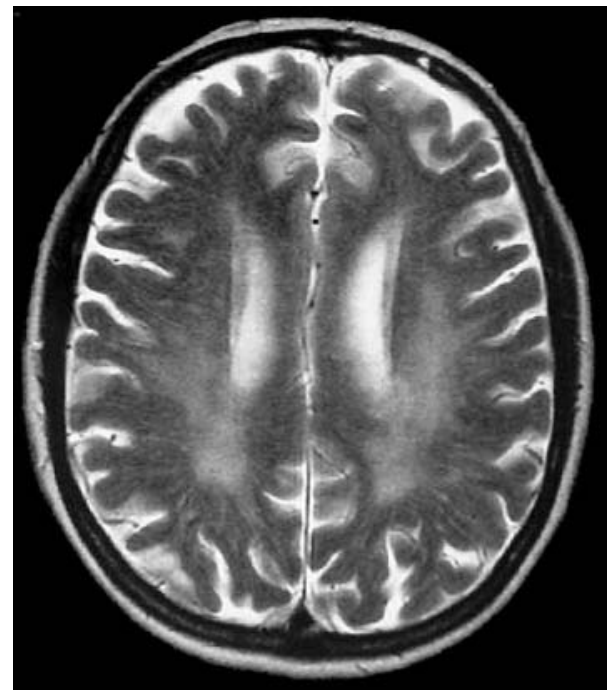

Figure $1 \mathrm{~T}_{2}$ weighted turbo spin echo MRI shows diffuse confluent hyperintensities in the periventricular and subcortical white matter of both parieto-occipital hemispheres, suggesting leucoencephalopathy. Staging MR images obtained 74 and $\mathbf{4 7}$ months previously showed no disease except for some unspecific microvascular lesions.

was free of neurological symptoms, but the MRI findings persisted.

The second patient with CSS, a 59 year old women with multiorgan involvement, had been treated with $3 \times 5$ million units IFNa/week subcutaneously since 1997. A cardiac relapse of her CSS and a transient psychotic episode, possibly related to the increased intake of prednisolone for the treatment of the cardiac relapse, occurred in January 2001. MRI of the head disclosed leucoencephalopathy. The CSF was normal. Infections and other causes were excluded. Psychotic symptoms subsided after withdrawal of IFN $\alpha$ and reduction of prednisolone. During follow up (October 2001, January 2003) the MRI findings remained unchanged, but remission was successfully re-induced with cyclophosphamide.

\section{DISCUSSION}

Leucoencephalopathy has been reported in a number of diseases necessitating immunosuppressive treatment such as autoimmune disorders-for example, systemic lupus erythematosus; neoplastic diseases-for example, leukaemias; and in organ transplant recipients. Several immunosuppressive or cytotoxic agents such as methotrexate, ciclosporin, flutarabine, and L-asparaginase, can cause leucoencephalopathy. ${ }^{3}$ Leucoencephalopathy can either be a result of the direct toxic effect of the drug or may be caused by infections during immunosuppressive treatment (for example, papovavirus infections like JC and BK or human immunodeficiency virus (HIV)). Further differential diagnoses include severe central nervous system manifestations of systemic vasculitides and diffuse cerebral neoplasms. A family history may give clues to the diagnosis of cerebral autosomal dominant arteriopathy with subcortical infarcts and leucoencephalopathy (CADASIL).

Infectious causes were excluded in both of our patients. The disease course with the detection of leucoencephalopathy by MRI during a relapse in the presence of previously successful IFN $\alpha$ treatment suggested either a cerebral manifestation of CSS or that IFN $\alpha$ was the cause of the leucoencephalopathy. Because cerebral lesions caused by vasculitides usually have a less diffuse and widespread character and CSF analysis showed no signs of inflammation, central nervous involvement of CSS appeared unlikely. In addition, multiple ischaemic lesions are extremely rare in CSS and were found in only one of 96 patients in a recent study. ${ }^{4}$

Leucoencephalopathy has been described in patients treated with IFN $\alpha$ for melanoma, leukaemia, lymphoma, or hepatitis C, usually presenting with somnolence, headache, disorientation, or short term memory loss, and resolving after IFN $\alpha$ is stopped. ${ }^{3-7}$ The causal relation between IFN $\alpha$ treatment and leucoencephalopathy is unclear. However, leucoencephalopathic lesions have been seen both in AicardiGoutieres syndrome, a human autosomal recessive progressive encephalopathy with raised CSF IFN $\alpha$ levels, and in transgenic mice overexpressing IFN $\alpha$ predominantly in astrocytes, suggesting that IFN $\alpha$ may induce leucoencephalopathy. ${ }^{8}$

These two cases suggest that IFN $\alpha$ may cause cerebral cytotoxicity also in CSS. Thus, long term treatment of CSS with IFN $\alpha$ should be restricted to patients who are unresponsive to other forms of treatment. Close monitoring of patients is mandatory and should include cerebral MRI in order to detect asymptomatic leucoencephalopathy at an early stage.

\section{Authors' affiliations}

C Metzler, P Lamprecht, B Hellmich, W L Gross, Department of Rheumatology, University Hospital of Schleswig-Holstein, Campus Luebeck, and Rheumaklinik Bad Bramstedt, Ratzeburger Allee 160, 23538 Luebeck, Germany

M Reuter, Department for Diagnostic Radiology, University Hospital of Schleswig-Holstein, Campus Kiel, Arnold-Heller Strasse 7, 24105 Kiel, Germany

A-C Arlt, Department of Neurology, Rheumaklinik Bad Bramstedt, Oskar-Alexander-Strasse 26, 24576 Bad Bramstedt, Germany

Correspondence to: Dr C Metzler, metzler@rheuma-zentrum.de

Accepted 7 February 2005

\section{REFERENCES}

1 Tatsis E, Schnabel A, Gross WL. Interferon-alpha treatment of four patients with the Churg-Strauss syndrome. Ann Intern Med 1998;129:370-4.

2 Termeer CC, Simon JC, Schopf E. Low-dose interferon alpha-2b for the treatment of Churg-Strauss-syndrome with prominent skin involvement. Arch Dermatol 2001; 137:1527-8.

3 Hinchey J, Chaves C, Appignani B, Breen J, Pao L, Wang A, et al. A reversible posterior leukoencephalopathy syndrome. N Engl J Med 1996;334:494-500.

4 Guillevin L, Cohen P, Gayraud M, Lhote F, Jarrousse B, Casassus P. ChurgStrauss syndrome. Clinical study and long-term follow-up of 96 patients. Medicine (Baltimore) 1999;78:26-37.

5 Nagafuji K, Harada N, Eto T, Hayashi S, Kamimura T, Gondo H, et al. Interferon-alpha treatment of acute lymphoblastic leukemia relapse after unrelated bone marrow transplantation. Int J Hematol 1998;67:63-8.

$6 \operatorname{Re} D$, Bamborschke S, Feiden W, Schroder R, Lehrke R, Diehl V, et al. Progressive multifokal leukoencephalopathy after autologous bone marrow transplantation and alpha-interferon immunotherapy. Bone Marrow Transplant 1999;23:295-8.

7 Kamar N, Kany M, Bories P, Ribes D, Izopet J, Durand D, et al. Reversible posterior leukoencephalopathy syndrome in hepatitis $C$ virus-positive longterm hemodialysis patients. Am J Kidney Dis 2001;37:E29.

8 Akwa Y, Hassett DE, Eloranta ML, Sandberg K, Masliah E, Powell H, et al. Transgenic expression of IFN-alpha in the central nervous system of mice protects against lethal neurotropic viral infection but induces inflammation and neurodegeneration. J Immunol 1998;161:5016-26. 


\title{
Anti- $\alpha$-fodrin autoantibodies are not useful diagnostic markers of primary Sjögren's syndrome
}

\author{
C Sordet, J E Gottenberg, J Goetz, D Bengoufa, R-L Humbel, X Mariette, J Sibilia
}

Ann Rheum Dis 2005;64:1244-1245. doi: 10.1136/ard.2004.026419

$\mathrm{F}$ odrin, an actin binding protein found in the cytoskeleton of most eukaryotic cells, would seem to be an important organ-specific autoantigen in Sjögren's syndrome (SS). Fodrin is, moreover, detected in the salivary glands of patients with primary SS (pSS) but not in controls. It was thus recently claimed that antibodies against $\alpha$-fodrin are a sensitive and specific serological marker for pSS. ${ }^{1}$

In this study we investigated the prevalence of autoantibodies against $\alpha$-fodrin in patients with pSS, as compared with healthy subjects and patients with other autoimmune diseases.

\section{METHODS AND RESULTS}

The study group included 107 patients with well defined pSS (mean age 57.5 years), 32 patients with systemic lupus erythematosus (SLE; mean age 40.1 years), 43 patients with rheumatoid arthritis (RA; mean age 59.0 years) with no signs of secondary SS, and 48 healthy blood donors (mean age 84.3 years). A diagnosis of SLE, RA, or pSS was established using the revised American College of Rheumatology criteria and the American-European Consensus Group criteria, ${ }^{2}$ respectively. The presence of anti- $\alpha$-fodrin (IgG and $\operatorname{IgA}$ ) antibodies in the serum was investigated using a commercial

Table 1 Anti- $\alpha$-fodrin antibodies in Sjögren's syndrome and other autoimmune diseases: analysis of published reports

\begin{tabular}{|c|c|c|c|c|c|c|c|}
\hline \multirow[b]{2}{*}{ Anti- $\alpha$-fodrin method } & \multirow[b]{2}{*}{ pSS } & \multicolumn{2}{|l|}{ sSS } & \multirow[b]{2}{*}{ SLE } & \multirow[b]{2}{*}{ RA } & \multirow[b]{2}{*}{ MS } & \multirow[b]{2}{*}{ Controls } \\
\hline & & SLE & RA & & & & \\
\hline \multicolumn{8}{|l|}{ Witte et $a^{\beta}$} \\
\hline Number & 85 & 15 & 7 & 50 & 12 & \multirow{4}{*}{ ND } & 160 \\
\hline ELISA & & & & & & & \\
\hline $\lg A$ & 64 & 47 & 86 & 2 & 17 & & $<1$ \\
\hline $\lg G$ & 55 & 40 & 43 & 2 & 42 & & 2 \\
\hline \multicolumn{8}{|l|}{ Witte et al' } \\
\hline Number & 136 & \multirow{4}{*}{ ND } & \multirow{4}{*}{ ND } & \multirow{4}{*}{ ND } & \multirow{4}{*}{ ND } & \multirow{4}{*}{ ND } & 207 \\
\hline ELISA & & & & & & & \\
\hline $\lg \mathrm{A}$ & 78.7 & & & & & & 2.9 \\
\hline $\lg G$ & 66.2 & & & & & & 3.4 \\
\hline \multicolumn{8}{|l|}{ De Seze ef $a^{p} 10$} \\
\hline $\begin{array}{l}\text { ELISA }(n) \\
\lg A \text { or } \lg G\end{array}$ & $\begin{array}{l}84 \\
64.5^{*} / 73.6 \dagger\end{array}$ & ND & ND & $\begin{array}{l}38 \\
15.8\end{array}$ & ND & $\begin{array}{l}60 \\
13.3\end{array}$ & $\begin{array}{l}160 \\
6.3\end{array}$ \\
\hline \multicolumn{8}{|l|}{ Zandbelt et $\left.a\right|^{\mu}$} \\
\hline ELISA (n) & 21 & 4 & ND & 6 & 12 & ND & 28 \\
\hline $\lg A$ & 43 & 75 & & 0 & 8.3 & & 0 \\
\hline $\lg G$ & 48 & 75 & & 0 & 50 & & 0 \\
\hline \multicolumn{8}{|l|}{ Ruffati et $a l^{5}$} \\
\hline ELISA (n) & 80 & ND & ND & 50 & 30 & ND & 60 \\
\hline $\lg A$ & 32.5 & & & 32 & 46.7 & & 1.7 \\
\hline $\lg G$ & 21.3 & & & 26 & 13.3 & & 8.3 \\
\hline \multicolumn{8}{|l|}{ Haneji et $a^{\beta}$} \\
\hline Number & 43 & 8 & ND & 21 & 14 & ND & 15 \\
\hline Immnublotting & 95.4 & 87.5 & & 0 & 0 & & 0 \\
\hline \multicolumn{8}{|l|}{ Watanabe et al78] } \\
\hline Number & 9 & 15 & ND & 44 & ND & ND & ND \\
\hline Immunoblotting & 78 & 60 & & 7 & & & \\
\hline \multicolumn{8}{|l|}{ Nordmark et $a^{\beta}$} \\
\hline Number & 56 & 14 & ND & ND & 53 & ND & ND \\
\hline Immunoprecipitation & 29 & 21 & & & 47 & & \\
\hline \multicolumn{8}{|l|}{ Current report } \\
\hline ELISA (normal < $15 \mathrm{U} / \mathrm{l}$ ) (n) & 107 & ND & ND & 32 & 43 & ND & 48 \\
\hline $\lg A$ & 17.7 & & & 25 & 23.3 & & 12.5 \\
\hline & 5.6 & & & 21.8 & 2.32 & & 0 \\
\hline Home made (normal $(0.280)(n)$ & 52 & & & ND & ND & & 29 \\
\hline $\lg A, \lg G, \lg M(\%)$ & 7.6 & & & & & & 0 \\
\hline
\end{tabular}


enzyme linked immunosorbent assay (ELISA) technique (Aesku Lab Diagnostika, Wendelsheim, Germany), which employs recombinant $93 \mathrm{kDa} \alpha$-fodrin as the antigen, and a home produced ELISA using as the antigen a synthetic $\alpha$-fodrin peptide corresponding to the 20 amino terminal residues of human $\alpha$-fodrin (RQKLEDSYRFQFFORDAEEL).

Only two (1.9\%) patients with pSS had both IgA and IgG anti- $\alpha$-fodrin antibodies. The home produced ELISA (antihuman $\operatorname{IgA}$, IgM, and IgG horseradish peroxidase conjugate) confirmed these results with only four positive patient in the pSS group $(n=52)$. Among the 19 patients with IgA anti- $\alpha$ fodrin antibodies, 15 patients also had anti-Ro60 antibodies and eight anti-La antibodies, while all six of the IgG positive sera contained anti-Ro60 and three of them anti-La antibodies.

\section{DISCUSSION}

The autoantibody response against $\alpha$-fodrin as detected by the ELISA test does not appear to be a relevant serological marker of pSS. However, some discrepancies with immunoblotting or immunoprecipitation data need to be discussed.

Our findings confirm previous reports of the low sensitivity $(<60 \%$ in the present study) of anti- $\alpha$-fodrin antibodies for the diagnosis of pSS using ELISA or immunoprecipitation techniques $^{3-5}$ (table 1). Conversely, the present data are discordant with the results of some other studies, ${ }^{16-10}$ which found a higher prevalence of these antibodies (up to 95\% in one study) in patients with pSS using immunoblotting ${ }^{67}$ or the same ELISA test as in our study. ${ }^{16} 910$

The low sensitivity of the ELISA methods could be related to the absence of dominant epitopes in either the synthetic oligopeptide or the recombinant $\alpha$-fodrin used in the commercial assay. Alternatively, a potential degradation of the recombinant protein cannot be ruled out. Thus the possibility of a lack of stability of the recombinant antigen led us to repeat the ELISA assay in all samples using a second kit from the same manufacturer, but with no improvement in the test sensitivity (data not shown). The reported discrepancies between different ELISA systems, which we also observed in the present study, would make such confirmation procedures mandatory.

The potential diagnostic value of anti- $\alpha$-fodrin antibodies for patients with pSS without anti-Ro60/La antibodies appears to be very limited, given the large overlap between the presence of anti- $\alpha$-fodrin and of anti-Ro60/La antibodies. Only four $(3.7 \%)$ patients with pSS were positive for IgA or IgG anti- $\alpha$-fodrin antibodies and negative for anti-Ro60/La.

The presence of anti- $\alpha$-fodrin antibodies seems to be of little help in discriminating between pSS and other autoimmune diseases such as SLE or RA. The prevalence of IgA antibodies against recombinant $\alpha$-fodrin was in fact lower in pSS $(17.7 \%)$ than in SLE $(25 \%)$ or RA $(23.3 \%)$. This apparent lack of specificity of anti- $\alpha$-fodrin antibodies, which has already been reported, requires confirmation using larger cohorts including various autoimmune diseases. Moreover, the presence of asymptomatic secondary SS in patients with RA or SLE cannot be ruled out. Thus all previous studies detected antibodies against $\alpha$-fodrin in subjects with primary or secondary SS (RA, SLE) (table 1).

In conclusion, the anti- $\alpha$-fodrin antibodies detected by ELISA appear to be neither a sensitive nor a specific serological marker of pSS and the presence of such antibodies would seem to be of limited discriminatory value and of little interest in daily rheumatological practice.

\section{Authors' affiliations \\ C Sordet, J E Gottenberg, J Goetz, D Bengoufa, R-L Humbel, X Mariette, J Sibilia}

Correspondence to: Professor J Sibilia, Service de rhumatologie, $\mathrm{CHU}$ Strasbourg- Hôpital de Hautepierre, 1, avenue molière, 67098

Strasbourg Cedex, France; jean.sibilia@wanadoo.fr

Accepted 2 January 2005

\section{REFERENCES}

1 Witte T, Matthias T, Oppermann M, Helmke K, Peter HH, Schmidt RE, et al. Prevalence of antibodies against alpha-fodrin in Siögren's syndrome: comparison of 2 sets of classification criteria. J Rheumatol 2003;30:2157-9.

2 Vitali C, Bombardieri S, Jonsson R, Moutsopoulos HM, Alexander EL, Carsons SE, et al. Classification criteria for Sjögren's syndrome: a revised version of the European criteria proposed by the American-European Consensus Group. Ann Rheum Dis 2002;61:554-8.

3 Nordmark G, Rorsman F, Ronnblom L, Cajander S, Taussig MJ, Kampe O, et al. Autoantibodies to alpha-fodrin in primary Sjögren's syndrome and SLE detected by an in vitro transcription and translation assay. Clin Exp Rheumatol 2003;21:49-56

4 Zandbelt MM Vogelzangs J, van de Putte LBA, van Venrooii WJ, van den Hoogen FHJ. Anti-alpha-fodrin antibodies do not add much to the diagnosis of Sjögren's syndrome. Arthritis Res Ther 2004;6:R33-8.

5 Ruffatti A, Ostuni P, Grypiotis P, Botsios C, Tonello M. Sensitivity and specificity for primary Siögren's syndrome of $\lg A$ and $\lg G$ anti-alpha-fodrin antibodies detected by ELISA. J Rheumatol 2004;31:504-7.

6 Haneji N, Nakamura T, Takio K, Yanagi K, Higashiyama H, Saito I, Identification of alpha-fodrin as a candidate autoantigen in primary Sjögren's syndrome, et al. Science 1997;276:604-7.

7 Watanabe T, Tsuchida T, Kanda N, Mori K, Hayashi Y, Tamaki K. Anti-alphafodrin antibodies in Siögren syndrome and lupus erythematosus. Arch Dermatol 1999;135:535-9.

8 Witte T, Matthias T, Arnett FC, Peter HH, Hartung K, Sachse C, et al. IgA and lgG autoantibodies against alpha-fodrin as markers for Sjögren's syndrome. Systemic lupus erythematosus. J Rheumatol 2000;27:2617-20.

9 De Sèze J, Dubucquoi S, Fauchais AL, Matthias T, Devos D, Castelnovo G, et al. Alpha fodrin autoantibodies in the differential diagnosis of mutiple sclerosis and Sïgren syndrome. Neurology 2003;61:268-9.

10 De Seze J, Dubucquoi S, Fauchais AL, Hachulla E, Matthias T, Lefranc D, et al. Autoantibodies against $\alpha$-fodrin in Sjögren's syndrome with neurological manifestations. J Rheumatol 2004;31:500-3.

\section{Successful treatment of acute visual loss in Muckle-Wells syndrome with interleukin 1 receptor antagonist}

\section{T Alexander, O Klotz, E Feist, K Rüther, G-R Burmester, U Pleyer}

M uckle-Wells syndrome (MWS) is a dominantly inherited autoinflammatory disease characterised by urticarial skin rash, intermittent fever, arthralgia, and the frequent development of systemic AA amyloidosis. It is caused by mutations in the gene known as NALP3 or CIAS, which encodes a member of the purine superfamily of death domain fold proteins that are implicated in the regulation of inflammation through activation of nuclear factor $\kappa \mathrm{B}$ (NF$\kappa \mathrm{B})$ and regulation of interleukin 1 (ILl) processing. ${ }^{2}$ Over recent years, therapeutic trials with the human recombinant 


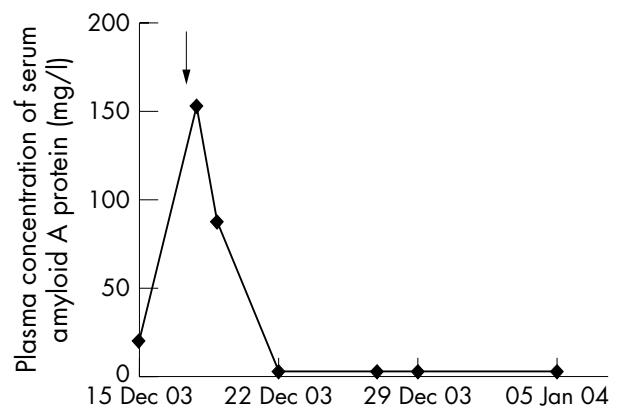

Figure 1 Serial measurement of serum amyloid $A$ concentration in one patient with MWS. The arrow indicates when treatment with anakinra began.

ILl receptor antagonist anakinra have reported encouraging results in patients with various autoinflammatory syndromes. ${ }^{3}$ We report here the unusual case of acute visual loss in a patient with MWS and its good response to anakinra.

\section{CASE REPORT}

A 70 year old woman with a history of a MWS associated with the NALP3 variant R260W was referred to our hospital with loss of vision in one eye that developed within days, accompanied by intermittent flash sensations.

On admission, she had an increased body temperature $\left(38^{\circ} \mathrm{C}\right)$ and urticarial rashes as typical signs of a flare of MWS. Residual visual acuity at admission was limited to hand motion perception and light-darkness discrimination. A slit lamp examination showed regular pseudophakia on both eyes with an afferent pupillary defect of the left eye. Ophthalmoloscopy of the left eye showed a pale optic nerve head oedema of 2 diopters. Pattern visual evoked potentials (VEPs) and flash VEPs of the affected eye were without responses. A kinetic visual field examination proved concentric constriction of the visual field of the left eye. Laboratory analysis showed a raised erythrocyte sedimentation rate of $36 \mathrm{~mm} / \mathrm{lst} \mathrm{h}$ and a C reactive protein of $32 \mathrm{mg} / \mathrm{l}$.

Initial treatment with systemic high dose glucocorticoids and one cycle of plasmapheresis had no influence on the visual disturbance. The patient then consented to undergo a therapeutic trial of anakinra (Kineret; Amgen) given by subcutaneous injection at a dose of $100 \mathrm{mg}$ daily, which is the dosage licensed for the treatment of rheumatoid arthritis.

Within 1 day of the first injection the rash and fever disappeared, and the patient reported a profound improvement in general wellbeing. The patient's sight of the left eye improved from hand movement upon referral to 0.3 within 10 days. In addition, the visual field defect recovered from band shaped to 50 degrees temporal and a vertical expansion of a maximal 20 degrees. The afferent pupillary defect persisted as well as VEP changes. As a serological marker, plasma concentration of serum amyloid A, which was markedly raised before treatment, normalised within 6 days and remained below $2 \mathrm{mg} / \mathrm{l}$ (normal $<10 \mathrm{mg} / \mathrm{l}$ ) on frequent testing for 3 weeks (fig 1).

\section{DISCUSSION}

In this unusual and dramatic manifestation of MWS we observed a remarkable clinical remission, including recovery of the patient's visual acuity and visual field associated with a profound serological remission using the ILl receptor antagonist anakinra.

To the best of our knowledge, this is the first description of acute visual loss in MWS. Being aware of the pale and swollen optic disc in our patient, we had to consider an anterior ischaemic optic neuropathy as a possible differential diagnosis. However, the clinical response using anakinra is strongly indicative for an association with an underlying inflammatory condition.

Visual disturbance is reported to be a clinical feature in patients with neonatal onset multisystem inflammatory disease (NOMID), an autoinflammatory disease that is also related to mutations in the NALP3 gene. ${ }^{5}$ Recent studies suggest that the same $N A L P 3$ genetic defect may cause vastly different phenotypes of hereditary fever syndromes. ${ }^{6}$ In this context, visual loss may possibly occur in patients considered to have MWS. The efficacy of anakinra in the treatment of visual disturbance in MWS strongly supports studies for this treatment of patients with NOMID, in which eye involvement is more common.

\section{Authors' affiliations}

T Alexander, E Feist, G-R Burmester, Department of Rheumatology and Clinical Immunology, University School of Medicine Berlin, Germany O Klotz, K Rüther, U Pleyer, Department of Ophthalmology Charité, University School of Medicine Berlin, Germany

Correspondence to: Mr T Alexander, Charité University School of Medicine Berlin, Schumannstr 20/21, D-10117 Berlin, Germany; tobias.alexander@charite.de

Accepted 28 December 2004

\section{REFERENCES}

1 Hoffman HM, Mueller JL, Broide DH, Wanderer AA, Kolodner RD. Mutation of a new gene encoding a putative pyrin-like protein causes familial cold autoinflammatory syndrome and Muckle-Wells syndrome. Nat Genet $2001 ; 29: 301-5$.

2 Wang L, Manji GA, Grenier JM, Al Garawi A, Merriam S, Lora JM, et al. PYPAF7, a novel PYRIN-containing Apaf1-like protein that regulates activation of NF-kappa B and caspase-1-dependent cytokine processing. J Biol Chem 2002;277:29874-80.

3 Hawkins PN, Lachmann HJ, McDermott MF. Interleukin-1-receptor antagonist in the Muckle-Wells syndrome. N Engl J Med 2003;348:2583-4.

4 Hawkins PN, Lachmann HJ, Aganna E, McDermott MF. Spectrum of clinical features in Muckle-Wells syndrome and response to anakinra. Arthritis Rheum 2004;50:607-12.

5 Aksentijevich I, Nowak M, Mallah M, Chae JJ, Watford WT, Hofmann SR, et al. De novo CIAS1 mutations, cytokine activation, and evidence for genetic heterogeneity in patients with neonatal-onset multisystem inflammatory disease (NOMID): a new member of the expanding family of pyrin-associated autoinflammatory diseases. Arthritis Rheum 2002;46:3340-8

6 Aganna E, Martinon F, Hawkins PN, Ross JB, Swan DC, Booth DR, et al. Association of mutations in the NALP3/CIAS1/PYPAF1 gene with a broad phenotype including recurrent fever, cold sensitivity, sensorineural deafness, and AA amyloidosis. Arthritis Rheum 2002;46:2445-52. 